Mar. Drugs 2010, 8, 577-593; doi:10.3390/md8030577

Review

\title{
The Chemical and Evolutionary Ecology of Tetrodotoxin (TTX) Toxicity in Terrestrial Vertebrates
}

\section{Charles T. Hanifin}

Hopkins Marine Station of Stanford University, 120 Oceanview Blvd. Pacific Grove CA, 93950, USA; E-Mail: charlesh@stanford.edu; Tel.: +01-1-831-655-6220

Received: 24 February 2010; in revised form: 3 March 2010 / Accepted: 8 March 2010 /

Published: 10 March 2010

\begin{abstract}
Tetrodotoxin (TTX) is widely distributed in marine taxa, however in terrestrial taxa it is limited to a single class of vertebrates (Amphibia). Tetrodotoxin present in the skin and eggs of TTX-bearing amphibians primarily serves as an antipredator defense and these taxa have provided excellent models for the study of the evolution and chemical ecology of TTX toxicity. The origin of TTX present in terrestrial vertebrates is controversial. In marine organisms the accepted hypothesis is that the TTX present in metazoans results from either dietary uptake of bacterially produced TTX or symbiosis with TTX producing bacteria, but this hypothesis may not be applicable to TTX-bearing amphibians. Here I review the taxonomic distribution and evolutionary ecology of TTX in amphibians with some attention to the origin of TTX present in these taxa.
\end{abstract}

Keywords: tetrodotoxin; TTX; Amphibia; Caudata; Anura; Salamandridae; Taricha; Notophthalmus; Cynops; Atelopus

\section{Introduction}

One of the most intriguing natural toxins isolated and described in the twentieth century is the neurotoxin tetrodotoxin (TTX), a non-proteinaceous, low molecular weight toxin (M.W. = 319.3) with extremely high potency (Human LD50 $=10.2 \mu \mathrm{g} / \mathrm{kg}$ ). Interest in TTX results from a number of striking circumstances, most significant of these is the vast array of taxa that are now known to possess TTX [1-3]. The presence of TTX in such a wide and disparate array of taxa has been taken as evidence that the ultimate origin of TTX in metazoans must be exogenous and there is good evidence that uptake of bacterially produced TTX is an important component of TTX toxicity in TTX-bearing marine metazoans [2-6]. However, this model has been questioned in regards to the TTX present in 
terrestrial taxa [1,7-10]. Arguments against bacterially sourced TTX in terrestrial metazoans derive, in part, from two major lines of evidence: (1) unlike marine species in which TTX is found in a wide array of taxonomic groups, TTX in terrestrial metazoans appears to be limited to a single class of vertebrates (Amphibia) with limited distribution within this class, and (2) the presence of multiple analogs of TTX (or saxitoxin (STX)) that are present only within a single species (or genus) such as chiriquitoxin (CHTX) and zetekitoxin (ZTX) in Atelopus or those (e.g., 6-epiTTX) that are common in the TTX profiles of some TTX-bearing amphibians, but are absent, or a very minor components in the TTX profiles of marine taxa or TTX producing bacteria [11-20], see also [1]. This review will focus on the taxonomic distribution and evolutionary ecology of TTX in amphibians as well as a brief discussion of the structure and pharmacology of amphibian specific TTX analogs.

\section{Background}

Tetrodotoxin takes its name from the Teleost fish order Tetrodontiformes from which the toxin was first isolated and described. Tetrodontid fish, which include puffer fish or fugu, have long been known to be toxic [21]. In fact, there is evidence that early Egyptians ( $5^{\text {th }}$ dynasty, ca $\left.2500 \mathrm{BC}\right)$ were aware of the toxicity associated with these fish [21]. Chinese herbal medical writings from the first or second century BC also describe pharmacological effects associated with the flesh and eggs of these fish [22]. Although little formal research was done on TTX until the late 1800's, European natural historians were aware of these toxic fish through historical texts (e.g., Kaempfer's History of Japan, from [22]). The earliest example of formal research into the pharmacology of TTX appears to have been Charles Remy's work in which he described the symptoms of TTX poisoning and documented the high concentrations of TTX present in the gonads of puffers (Remy, 1883, from [21]). Later work in the $19^{\text {th }}$ century included a comprehensive pharmacology of TTX by Takahashi in 1889, from [21].

Tetrodotoxin was first formally named in 1909 by Tahara, from [23], who prepared a crude extract from puffer fish. Pure, crystalline TTX was not isolated until 1950 when A. Yokoo isolated TTX from the ovaries of Fugu rubripes and described it as spheroidine after a genus of puffer fish [23]. The nomenclature of TTX was solidified in 1952 when K. Tsuda and M. Kawamura isolated an identical toxin using chromatographic methods and named it tetrodotoxin (from [23]).

The complete molecular structure of TTX was first described in 1964 at the Natural Products Symposium of the International Union of Pure and Applied Chemistry by a total of 4 different lab groups including K. Tsuda, T. Goto, R. B. Woodward, and H. S. Mosher [21]. It is important to note that while three of these groups had been working on toxin isolated from puffer fish, the Mosher group was reporting on compound they named tarichatoxin isolated from eggs of the newt Taricha torosa [24-26]. Since the 1960's the chemistry, pharmacology, and synthesis of TTX has been the subject of a voluminous body of work, see [27], as well as [1,3,21,23,28-31] for partial reviews.

The pharmacology of TTX is well studied and will not be detailed here, see [27] for recent review. The gross pharmacological effects of TTX (i.e., muscle paralysis and/or death) have long been recognized [22,32-35], also see [21], but it was not until the 1950's that a more detailed understanding of the pharmacological properties of TTX began to emerge. Tetrodotoxin was shown to block sodium currents in excitable membranes (e.g., nerve and muscle tissue) [36-38]. It is now understood that TTX binds and blocks voltage-gated sodium $\left(\mathrm{Na}^{+}\right)$channels with remarkably high specificity thereby 
prevented in the influx of $\mathrm{Na}^{+}$. These ion channels are, in part, responsible for the initiation and propagation of action potentials in most metazoans [28,36,39-41]. The current model of the interaction between TTX and voltage-gated $\mathrm{Na}^{+}$channels is that the positively charged amino end of TTX forms complex electrostatic bonds with two charged rings of amino-acid residues in the outer pore of the sodium channel (the selectively filter) [29,30,42]. The remainder of the TTX molecule then blocks the outer pore preventing the influx of $\mathrm{Na}^{+}$ions and the associated currents required for membrane depolarization and action potential initiation.

\section{TTX and TTX Analogs in Amphibians}

Tetrodotoxin is a guanidium ion with a complex oxygenated cyclohexane framework with both guanidine and ortho-acid functional groups (Figure 1) [27,43,44]. Numerous natural, semi-synthetic, and synthetic analogs of TTX have been reported, reviewed in [15]. A detailed review of these TTX analogs is beyond the scope of this review, but these analogs can be broadly grouped as either hemilactal, or lactone variants $[15,44]$. Amphibians have been an especially plentiful source of TTX analogs $[11,12,14,16,19,45-47]$. The hemilactal forms of TTX are the more common naturally occurring analogs (Figure 1). Many of the commonly seen analogs (e.g., 4-epiTTX and anhyrdoTTX) are likely conversion or equilibrium products of TTX and are commonly seen in all TTX-bearing taxa [44]. As such they are of interest to biochemists and may shed light on the synthesis of TTX but may not be informative in regards to possible differences in the TTX toxicity of marine versus terrestrial taxa. However, other analogs (e.g., CHTX, Figure 1) appear to be present only in amphibians and restricted to one or two closely related species (e.g., CHTX and ZTX are found only in the toad genus Atelopus) $[16,19,46,48]$. These analogs are extremely potent and have toxicities equivalent or greater than TTX itself $[11,14,47,49]$. Understanding their distribution and origin are critically important in the exploration of TTX in Amphibians. The unique structure of these analogs does not inherently support an endogenous origin of TTX in amphibians. Multiple alkaloid toxins unique to species or genera of dendrobatid frogs are now known to come from precursors present in arthropod prey of these frogs [50]. It is possible that the presence of CHTX and ZTX in Atelopus results from similar processes but there is little evidence that supports this hypothesis (but see, [19] for recent work).

Other analogs present in amphibians are not as potent as TTX (e.g., 6-epiTTX, Figure 1), but are of interest because they do not appear to be cross convertible with TTX and appear to form as a result of stereo-specific reactions $[12,44]$. One of these analogs (6-epiTTX) was first described in the newt genus Cynops [12]. This analog can represent a significant portion of the total TTX present in TTXbearing salamanders but appears to be relatively rare in marine taxa $[12,13,17,18,51-53]$. In populations of Taricha the relative levels of TTX to 6-epiTTX are invariant within a population, but display significant variation among population [54]. Similar patterns have also been documented in populations of Cynops pyrrhogaster in Japan [55]. In Taricha this variation in toxin profiles can occur over very short distances $(<20 \mathrm{~km})$ and among populations that occupy the same watershed as well as similar habitats (unpublished data). Spatial variation in analog profiles has been seen as an additional argument in favor on an exogenous origin for TTX in metazoans [3], but can also be seen to favor an endogenous origin if seen in the context of generic variation associated with the genes that comprise the biosynthetic pathway of TTX amphibians versus marine bacteria. 
Figure 1. The structure of TTX as well as some TTX analogs associated with amphibians (from Yostu-Yamashita 2001) [15].

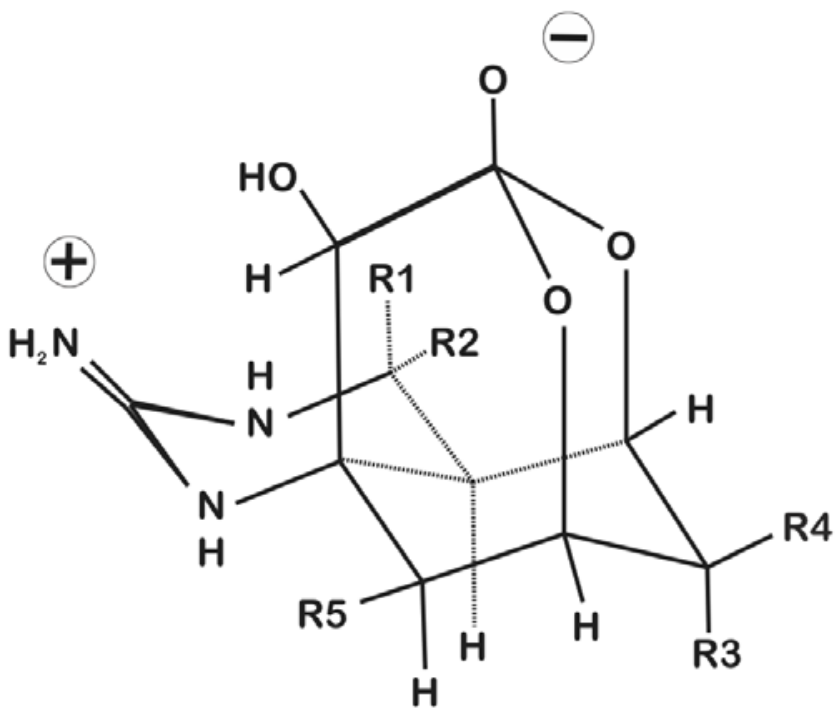

\begin{tabular}{lccccc}
\hline & R1 & R2 & R3 & R4 & R5 \\
\hline TTX & $\mathrm{H}$ & $\mathrm{OH}$ & $\mathrm{OH}$ & $\mathrm{CH}_{2} \mathrm{OH}$ & $\mathrm{OH}$ \\
4-epiTTX & $\mathrm{OH}$ & $\mathrm{H}$ & $\mathrm{OH}$ & $\mathrm{CH}_{2} \mathrm{OH}$ & $\mathrm{OH}$ \\
6-epiTTX & $\mathrm{H}$ & $\mathrm{OH}$ & $\mathrm{CH}_{2} \mathrm{OH}$ & $\mathrm{OH}$ & $\mathrm{OH}$ \\
11-deoxyTTX & $\mathrm{H}$ & $\mathrm{OH}$ & $\mathrm{OH}$ & $\mathrm{CH}_{3}$ & $\mathrm{OH}$ \\
CHTX & $\mathrm{H}$ & $\mathrm{OH}$ & $\mathrm{OH}$ & $\mathrm{CH}(\mathrm{OH}) \mathrm{CH}\left(\mathrm{NH}_{3}+\right) \mathrm{COO}-$ & $\mathrm{OH}$ \\
\hline
\end{tabular}

\section{Taxonomic Distribution of TTX and TTX Analogs in Amphibians}

Although TTX is broadly distributed across taxonomic classes in aquatic species (reviewed in [3]), in terrestrial taxa TTX appears to be limited to two orders (Anura, and Caudata) of a single class (Amphibia) of vertebrates [1]. Tetrodotoxin (or TTX analogs) have been identified in a total of 28 species representing 10 genera and six (or five, see below) families (Anura: Bufonidae, Rhacophoridae, Brachycephalidae, Dendrobatidae; Caudata: Ambystomatidae, Salamandridae) (Table 1), but appear to be absent in a total of 38 examined species (Table 2), reviewed in [1].

The earliest confirmation of TTX in amphibians was in eggs of the California Newt Taricha torosa (Order: Caudata, Family: Salamandridae) [24-26]. However, the presence of a neurotoxin in skin and flesh of this species that had functional similarities to TTX had been known since the 1930's [33-35,56,57]. The discovery of TTX, the TTX analog CHTX and the saxitoxin analog ZTX in the toad genus Atelopus (Order: Anura, Family: Bufonidae) was the first evidence of TTX in a nonsalamandrid [46], but see also [58] for earlier work. 
Table 1. Distribution and levels of TTX and TTX analogs in amphibians.

\begin{tabular}{|c|c|c|c|c|c|}
\hline Order & Family, Species & $\begin{array}{l}\text { Primary } \\
\text { Toxin }\end{array}$ & $\begin{array}{l}\text { Estimated amount of } \\
\text { TTX (or equivalents) } \\
\text { per individual (ug) }\end{array}$ & Additional Analogs & References \\
\hline \multirow[t]{15}{*}{ Caudata } & Ambystomatidae & & & & \\
\hline & Ambystoma tigrinum & TTX & $12.6-17.6$ & 6-epiTTX, 11-deoxyTTX & {$[13]$} \\
\hline & Salamandridae & & & & \\
\hline & Cynops ensicauda & TTX & $9.6-1540$ & 6-epiTTX, 11-deoxyTTX & {$[12,13,26,59]$} \\
\hline & Cynops pyrrhogaster & TTX & $8-616$ & 6-epiTTX, 11-deoxyTTX & {$[13,26,55,59-61]$} \\
\hline & $\begin{array}{l}\text { Notophthalmus } \\
\text { viridescens }\end{array}$ & TTX & $9.6-220$ & 6-epiTTX, 11-deoxyTTX & {$[17,18,26,51,59,60,62]$} \\
\hline & $\begin{array}{l}\text { Paramesotriton } \\
\text { hongkongensis }\end{array}$ & TTX & $8-11$ & & {$[13,60]$} \\
\hline & Taricha granulosa & TTX & $<1-14,000$ & 6-epiTTX, 11-deoxyTTX & {$[8,9,13,24-26,45,54,59,60,63-67]$} \\
\hline & Taricha rivularis & TTX & $96-550$ & & {$[56,59,60,68]$} \\
\hline & Taricha torosa & TTX & $<1-3000$ & 6-epiTTX & {$[59,60,66,67]$} \\
\hline & Triturus alpestris & TTX & $0-41$ & 6-epiTTX & {$[13,18,59]$} \\
\hline & Triturus cristatus & TTX & $0-9$ & 6-epiTTX & {$[18,59]$} \\
\hline & Triturus helveticus & TTX & $0-8$ & 6-epiTTX & {$[18]$} \\
\hline & Triturus marmoratus & TTX & $0.16-0.66$ & & {$[26,59]$} \\
\hline & Triturus vulgaris & TTX & $0-8$ & 6-epiTTX, 11-deoxyTTX & {$[13,18,59]$} \\
\hline \multirow[t]{19}{*}{ Anura } & Brachycephalidae & & & & \\
\hline & $\begin{array}{l}\text { Brachycephalus } \\
\text { ephippium }\end{array}$ & TTX & $<1-22.4$ & 6-epiTTX, 11-deoxyTTX & {$[20,52,53,69]$} \\
\hline & Brachycephalus pernix & TTX & 5 & & {$[53]$} \\
\hline & Dendrobatidae & & & & \\
\hline & Colostethus inquinalis & TTX & $0.1-1.4$ & & {$[70]$} \\
\hline & Bufonidae & & & & \\
\hline & Atelopus chiriquiensis & CHTX & 33 (TTX), 77 (CHTX) & TTX & {$[14,19,46,47,71]$} \\
\hline & Atelopus glyphus & CHTX & $34-79$ & & {$[19]$} \\
\hline & Atelopus ignescens & TTX & $<1.0-1.5$ & & {$[70]$} \\
\hline & Atelopus limosus & CHTX & $8-19$ & & {$[19]$} \\
\hline & Atelopus oxyrhynchus & TTX & $32-198$ & & {$[48,72]$} \\
\hline & Atelopus peruensis & TTX & $3.2-4.4$ & & {$[73]$} \\
\hline & Atelopus spumarius & TTX & $1.6-3.5$ & & {$[70]$} \\
\hline & Atelopus spurelli & TTX & $<1-1.1$ & & {$[70]$} \\
\hline & Atelopus subornatus & TTX & $3.2-17.6$ & & {$[73]$} \\
\hline & Atelopus varius & TTX & $16-26$ & & {$[19,46,70,74]$} \\
\hline & Atelopus zeteki & ZTX & $<1-264$ & & {$[19,46,58,70,75]$} \\
\hline & Rhacophoridae & & & & \\
\hline & Polypedates sp. & TTX & $4.8-198$ & & {$[76]$} \\
\hline
\end{tabular}

${ }^{a}$ Estimates of per individual TTX in $\mu \mathrm{g}$ are based, in part, on conversion from mouse units (MU) taken from Daly 2004 [1]. A mouse unit corresponds to $0.16-0.22 \mu \mathrm{g}$ of TTX. CHTX and ZTX are based on TTX equivalents. ${ }^{\mathrm{b}}$ Only the presence of 6-epiTTX and 11-deoxyTTX are identified here for additional congeners see Daly 2004 [1]. 
Since Daly's review [1], TTX has been identified (or confirmed) in two additional species of Brachycephalus (B. ephippium, and B. pernix [53]), four species of the European newt genus Triturus (Tr. vulgaris, Tr. alpestris, Tr. cristatus, and Tr. helveticus, [18]), three species of Atelopus (A. varius, A. chiriquiensis, and A. zeteki, [19]) (Table 1). Recent work has also confirmed the presence of 6-epiTTX and/or 11-oxoTTX in Triturus [18] and Brachycephalus [53] as well as the presence of CHTX in an Atelopid species other than A. chiriquiensis (e.g., A. limosus and A. glyphus [19]) (Table 1).

The identification of TTX in two families of Caudata is somewhat problematic. Although TTX has been identified in both the Salamandridae and Ambystomatidae (Table 1), I would argue that in Caudates, TTX is likely limited to a subset of related genera (Taricha, Notophthalmus, Triturus, Cynops, and Paramesotriton) in the family Salamandridae (see also [1]) and that reports of the presence of TTX in the Ambystomatidae are likely erroneous. With the exception of two reports (both apparently based on results from the same specimen) of TTX in Ambystoma tigrinum [12,13], there is no evidence of the presence of TTX in a non-salamandrid Caudate (Table 1, Table 2). Earlier investigations specifically examined A. tigrinum for the presence of TTX and did not detect any evidence of TTX of a TTX-like toxin [59] nor did an additional examination of a single Ambystoma tigrinum using HPLC-FLD by this author (unpublished data). More significantly, species of Ambystoma are highly sensitive to TTX [26,33,57,63], yet other TTX-bearing salamanders (as well as other TTX-bearing vertebrates) are highly resistant to TTX $[22,25,26,32,60,63,77,78]$. Given that the report of TTX in this species is based on a single animal with questionable provenance [12], a reexamination of the presence of TTX in Ambystoma seems to be in order.

Table 2. Species of Amphibians that do not appear to possess TTX.

\begin{tabular}{lll}
\hline Order & Family, Species & Reference \\
\hline Caudata & Ambystomatidae & \\
& Ambystoma tigrinum & {$[59]$} \\
& Amphiumadae & \\
& Amphiuma means & {$[59]$} \\
& Cryptobranchidae & \\
& Cryptobranchus alleganiensis & {$[59]$} \\
& Plethidontidae & \\
& Batrachoseps attenuatus & {$[59]$} \\
& Ensatina eschscholtzi & {$[59]$} \\
& Aneides lugubris & {$[59]$} \\
& Proteidae & \\
& Necturus maculosus & {$[59]$} \\
& Salamandridae & \\
& Salamandra salamandra & {$[59]$} \\
& Echinotriton andersoni & From Miyazawa, 2001[2] \\
Anura & Bufonidae & \\
& Atelopus certus & {$[19]$} \\
& Bufo boreas & {$[59]$} \\
& Bufo regularis & {$[70]$} \\
& Dendrophyryniscus minutus & {$[70,73]$} \\
\hline
\end{tabular}


Table 2. Cont.

\begin{tabular}{lc}
\hline Melanophryniscus moreirae & {$[70]$} \\
Melanophrynicus stelzneri & {$[73]$} \\
Oreophrynella sp. & {$[73]$} \\
Denrobatidae & \\
Aromabates nocturnus & {$[70]$} \\
Dendrobates pumilio & {$[70]$} \\
Phyllobates bicolor & {$[70]$} \\
Hylidae & \\
Cyclorana australis & {$[70]$} \\
Hemiphractus fasciatus & {$[70]$} \\
Hyla cinera & {$[59]$} \\
Litoria albuguttata & {$[70]$} \\
Nyctimystes tympanocryptis & {$[70]$} \\
Osteocephalus taurinus & {$[70]$} \\
Phrynohyas venulosa & {$[70]$} \\
Leptodactylidae & \\
Eleutherodactylus gollmeri & {$[70]$} \\
Microhylidae & \\
Otophryne robusta & {$[70]$} \\
Phrynomerus bifasciatus & {$[70]$} \\
Scaphiophryne marmorata & {$[70]$} \\
Mantellidae & \\
Mantella aurantiaca & {$[70]$} \\
Myobatrachidae & {$[70]$} \\
Heleioporus albopunctatus & {$[70]$} \\
Notaden nichollsi & {$[70]$} \\
Pseudophryne corroboree & \\
Pipidae & {$[59]$} \\
Xenopus laevis & {$[70]$} \\
Ranidae & \\
Rana pipiens & \\
Rana rugulosa & \\
Rana septentrionalis & \\
& \\
\hline
\end{tabular}

\section{Ecology and Evolution of TTX Toxicity in Amphibians}

The ecological role of TTX in metazoans (both marine and terrestrial) is of critical importance, yet it is understudied and poorly understood. Bioaccumulation of TTX (whether through synthesis, symbiosis with bacteria, or dietary uptake and processing) likely results in a significant cost to TTX-bearing taxa [79]. Additionally, there is evidence that TTX resistance (a necessary trait for accumulation of TTX in TTX-bearing vertebrates) may also come with its own cost $[29,80,81]$. As a result, metazoans that possess TTX must gain some benefit from their TTX toxicity that outweighs these costs [79].

Amphibians are present on every continent except for Antarctica and occupy a diverse array of habitats [82]. Their slow speed, soft bodies, and habitat choices make them attractive targets of 
predators. In response, amphibian species worldwide have evolved a pharmacopeia of toxic and noxious compounds [83]. These compounds protect amphibians from predation [7,84-87] as well as infection from pathogens (both fungal and bacterial) [88-90]. The TTX present in TTX-bearing amphibians is also assumed to play a defensive role and there is good data to support the hypothesis $[1,83]$.

The presence of TTX is associated with aposematic coloration in TTX-bearing amphibians. Species of Atelopus, Brachycephalus, and Colostethus that possess TTX (or CHTX) also possess aposematic coloration, but non-TTX bearing species of Brachycephalus do not appear to have TTX [7,53,83]. In one study aposematic efts of Notophthalmus were found to be more toxic than non-aposematic adults [59], but another found the opposite pattern [51]. Salamandrid newts are well known for an array of defensive warning postures [84,91]. TTX-bearing salamandrid newts (e.g., Taricha, Cynops, and Notophthalmus) engage in a well-documented warning pose in which they display orange, red, or yellow present on their ventral surface [92]. In Taricha, at least, this warning posture is frequently associated with secretion from dorsal glands that contain TTX (pers. obs.).

Defensive compounds of amphibians are typically associated with secretory skin glands [82,84,93-97]. In TTX-bearing amphibians levels of TTX are typically much higher in skin than in other tissues (except for eggs see below) [8,13,17,18,20,46,53,59,64]. Furthermore there is direct evidence than TTX is contained and sequestered in granular skin glands of TTX-bearing salamanders [61,64,98]. Taricha and Cynops newts actively secrete TTX when directly stimulated or when they encounter a snake predator [8,61,99]. Skin secretions from Taricha [25,60,63,100-102], and Notophthalmus [103-109], are known to be lethal to (or deter predation by) potential predators. Reports associated with the toxicity of Polypedates also indicate that secretions from this species appear to be toxic to potential predators [76]. These results are not surprising given the high levels (and potency) of TTX present in these taxa are further support for a defensive role of TTX in amphibians.

The best-documented example of the defensive role of TTX is the coevolutionary interaction between Taricha newts and snake predators. Newts of the genus Taricha have long been known to possess a TTX resistant predator (garter snakes of the genus Thamnophis) [56,57,63]. In some populations that co-occur with newts, garter snakes have evolved resistance to TTX allowing them to prey on toxic newts. This predation by snakes has generated a coevolutionary arms race centered on TTX levels in newts and TTX-resistance in garter snakes [67,110-113]. Although the strength of coevolution between these species is spatially variable, these arms races have generated elevated (and extreme) levels of TTX and TTX resistance in some populations of Taricha and Thamnophis [54,64,67,110,111,113-116]. Tetrodotoxin levels present in Taricha (and other TTX-bearing Salamandridae) are significantly higher than TTX-bearing anurans (Table 1, also see [1]). Individuals from some populations of Taricha granulosa have been measured to possess up to $14 \mathrm{mg}$ of TTX [67]. In Taricha, these elevated levels of TTX result from coevolution with garter snakes [67,111]. There is no direct evidence that similar predator-prey interactions have driven elevated TTX levels in other species of Salamandridae, but populations of both Triturus in Germany and Cynops in Japan show patterns of spatial variability in TTX levels $[18,55]$ and environmental factors alone seem an unlikely explanation for these differences or the elevated levels of TTX seen in salamanders. 
Tetrodotoxin also serves to defend the eggs of TTX-bearing amphibian species. Ecologically relevant levels of TTX have been found in the eggs of TTX bearing salamanders and Atelopus $[1,25,46,59,65,71,100]$. In Taricha, individual eggs can possess upwards of $2 \mu \mathrm{g}$ of TTX and the investment of TTX in eggs appears to be an active process [65]. Recent evidence indicates that Caddis Fly larva are possible predators of Taricha eggs and that increased levels of TTX in the eggs of newts may deter predation by these insect predators [117].

The presence of TTX in adult newts (and possibly in Anurans) has far reaching ripple effects in the communities in which these animals exist [118]. There are at least two mimicry systems associated with the presence of TTX in N. American newt genera (Taricha and Notophthalmus, [119-122]). Developing evidence suggests that garter snake predators of newts may be capable of sequestering TTX obtained from newts as defense against their own predators [79, 99]. Tetrodotoxin also seems to serve as warning chemical; allowing larval Taricha to sense and avoid cannibalistic predation by adults $[118,123,124]$.

\section{Conclusions in Regards to the Origin/Biosynthesis of TTX in Amphibians}

The ultimate origin or biosynthesis of TTX in amphibians is still a source of some controversy $[1,3,8,18,19,67,125]$. A compelling argument has been made that TTX present in marine metazoans is derived from bacterial sources (reviewed in [3] but see [126]). However little progress has been made in directly elucidating the genes and enzymatic pathways responsible for the biosynthesis of TTX in bacteria. Studies of TTX biosynthesis in amphibians are mixed and evidence favoring an endogenous origin of TTX in these taxa is indirect at best. In the only study to directly look at TTX synthesis in Taricha, animals fed a series of radioactive-labeled (potential) TTX precursors and small molecules did not show evidence of uptake of the radioactive-label [66]. Adult Atelopus varius raised in captivity did not possess measurable levels of TTX or TTX like toxins nor did captive Cynops pyrrhogaster $[3,74]$. However Taricha granulosa kept in captivity and feed earthworms were capable of maintaining (or increasing) high levels of TTX over multiple years and captive T. granulosa also regenerate large amounts (up to $3 \mathrm{mg}$ ) of TTX in relatively brief periods when fed a non-toxic diet [8,9,45]. Similar maintenance of TTX levels over 3 years in captivity has been seen in Atelopus oxyrhynchus [48] An examination of the skin and glands of T. granulosa did not yield any evidence of symbiotic TTX producing bacteria in granular secretory glands associated with TTX in salamanders [10]. More compelling, perhaps, is the limited distribution of TTX analogs in various species of amphibians [1,7-9,83]. Chiriquitoxin and ZTX have only been described in species of Atelopus [1,19]. The 6-epiTTX stereoisomer of TTX is common in amphibians and can make up a substantive portion of the total TTX's present in some species (and/or populations) [12,13,17,18,44,54], yet it appears to be very rare in marine species. In Taricha the ratio of 6-epiTTX to total TTX show little (or no variation) within a locality, but can vary dramatically across localities; a pattern that is difficult to understand in the context of a dietary or symbiotic source of TTX [54]. Finally, evidence from 40 years of study coevolution between Taricha and Thamnophis strongly suggest that the elevated (and extreme) levels of TTX seen in the genus likely results from coevolution with snakes and that the evolution of extreme toxicity may have occurred over a relatively short time frame [67,111,127]. These results suggest, in 
turn, that TTX levels in this genus (and possibly in other salamanders or amphibians) are (to some degree) under genetic control.

\section{Future Directions}

A century after its formal naming interest in TTX is still strong and the molecule is still the focus of extensive research. Although much progress has been made, fundamental questions associated with the synthesis and taxonomic distribution of TTX still remain. The central question facing workers interested in the chemical ecology and evolutionary biology of TTX toxicity in amphibians is still that of an endogenous versus exogenous origin of TTX. Compelling, yet indirect, evidence exists for either position. Any convincing resolution to this problem will have to address the following issues: (1) The presence of TTX analogs that are limited to a single species (or genus) of amphibian, (2) the apparent abundance of TTX analogs such as 6-epiTTX and 11-deoxyTTX in the toxin profiles of TTX-bearing amphibians and their corresponding paucity in marine taxa, (3) the extreme spatial variation in toxin profiles and TTX levels seen within populations of some terrestrial TTX-bearing species, (4) the longevity of TTX in (some) captive TTX-bearing species, and (5) the extremely limited taxonomic distribution of TTX in terrestrial vertebrates.

\section{Acknowledgments}

S. Geffeney provided helpful comments on the preparation of this manuscript. Funding to CTH through an NIH/NRSA award (5F32GM80132).

\section{References and Notes}

1. Daly, J.W. Marine toxins and nonmarine toxins: Convergence or symbiotic organisms. J. Nat. Prod. 2004, 67 (8), 1211-1215.

2. Miyazawa, K.; Noguchi, T. Distribution and origin of tetrodotoxin. J. Toxicol.: Toxin Rev. 2001, 20 (1), 11-33.

3. Noguchi, T.; Arakawa, O. Tetrodotoxin--distribution and accumulation in aquatic organisms, and cases of human intoxication. Mar. Drugs 2008, 6 (2), 220-242.

4. Do, H.K.; Kogure, K.; Simidu, U. Identification of deep-sea-sediment bacteria which produce tetrodotoxin. Appl. Environ. Microbiol. 1990, 56 (4), 1162-1163.

5. Noguchi, T.; Jeon, J.-K.; Arakawa, O.; Sugita, H.; Deguchi, Y.; Shida, Y.; Hashimoto, K. Occurrence of tetrodotoxin and anhydrotetrodotoxin in Vibrio sp. isolated from the intestines of a xanthid crab, Atergatis floridus. J. Biochem. 1986, 99, 311-314.

6. Yasumoto, T.; Yasumura, D.; Yotsu, M.; Michishita, T.; Endo, A.; Kotaki, Y. Bacterial production of tetrodotoxin and anhydrotetrodotoxin. Agric. Biol. Chem. 1986, 50 (3), 793-795.

7. Daly, J.W.; Myers, C.W.; Whittaker, N. Further classification of skin alkaloids from neotropical poison frogs (Dendrobatidae), with a general survey of toxic/noxious substances in the amphibia. Toxicon 1987, 25 (10), 1023-1095.

8. Cardall, B.L.; Brodie, E.D., Jr.; Brodie, E.D., III; Hanifin, C.T. Secretion and regeneration of tetrodotoxin in the rough-skin newt (Taricha granulosa). Toxicon 2004, 44 (8), 933-938. 
9. Hanifin, C.T.; Brodie, E.D., III; Brodie, E.D., Jr. Tetrodotoxin levels of the rough-skin newt, Taricha granulosa, increase in long-term captivity. Toxicon 2002, 40 (8), 1149-1153.

10. Lehman, E.M.; Brodie, E.D., Jr.; Brodie, E.D., III. No evidence for an endosymbiotic bacterial origin of tetrodotoxin in the newt Taricha granulosa. Toxicon 2004, 44 (3), 243-249.

11. Kim, Y.H.; Kim, Y.B.; Yotsu-Yamashita, M. Potent neurotoxins: tetrodotoxin, chiriquitoxin, and zetekitoxin from Atelopus frogs in Central America. Toxin Rev. 2003, 22 (4), 521-532.

12. Yasumoto, T.; Yotsu, M.; Murata, M. New tetrodotoxin analogues from the newt Cynops ensicauda. J. Am. Chem. Soc. 1988, 110, 2344.

13. Yotsu, M.; Iorizzi, M.; Yasumoto, T. Distribution of tetrodotoxin, 6-epitetrodotoxin, and 11-deoxytetrodotoxin in newts. Toxicon 1990, 28 (2), 238-241.

14. Yotsu, M.; Yasumoto, T.; Kim, Y.H.; Naoki, H.; Kao, C.Y. The structure of chiriquitoxin from the Costa Rican frog Atelopus chiriquiensis. Tetrahedron Lett. 1990, 31 (22), 3187-3190.

15. Yotsu-Yamashita, M. Chemistry of puffer fish toxin. J. Toxicol.: Toxin Rev. 2001, 20 (1), $51-66$.

16. Yotsu-Yamashita, M.; Kim, Y.H.; Dudley, S.C., Jr.; Choudhary, G.; Pfahnl, A.; Oshima, Y.; Daly, J.W. The structure of zetekitoxin AB, a saxitoxin analog from the Panamanian golden frog Atelopus zeteki: a potent sodium-channel blocker. Proc. Natl. Acad. Sci. USA 2004, 101 (13), 4346-4351.

17. Yotsu-Yamashita, M.; Mebs, D. The levels of tetrodotoxin and its analogue 6-epitetrodotoxin in the red-spotted newt, Notophthalmus viridescens. Toxicon 2001, 39 (8), 1261-1263.

18. Yotsu-Yamashita, M.; Mebs, D.; Kwet, A.; Schneider, M. Tetrodotoxin and its analogue 6-epitetrodotoxin in newts (Triturus spp.; Urodela, Salamandridae) from southern Germany. Toxicon 2007, 50 (2), 306-309.

19. Yotsu-Yamashita, M.; Tateki, E. First report on toxins in the Panamanian toads Atelopus limosus, A. glyphus and A. certus. Toxicon 2010, 55 (1), 153-156.

20. Pires, O.R., Jr.; Sebben, A.; Schwartz, E.F.; Largura, S.W.; Bloch, C., Jr.; Morales, R.A.; Schwartz, C.A. Occurrence of tetrodotoxin and its analogues in the Brazilian frog Brachycephalus ephippium (Anura: Brachycephalidae). Toxicon 2002, 40 (6), 761-766.

21. Fuhrman, F.A. Tetrodotoxin, tarichatoxin, and chiriquitoxin: historical perspectives. Ann. N.Y. Acad. Sci. 1986, 479, 1-14.

22. Kao, C.Y. Tetrodotoxin, saxitoxin and their significance in the study of excitation phenomena. Pharmacol. Rev. 1966, 18 (2), 997-1049.

23. Hashimoto, Y. Marine Toxins and Other Bioactive Marine Metabolites; Japan Scientific Societies Press: Tokyo, Japan, 1979; p. 369.

24. Brown, M.S.; Mosher, H. Tarichatoxin: Isolation and purification. Science 1963, 140, 295-296.

25. Buchwald, H.D.; Durham, L.; Fischer, H.G.; Harada, R.; Mosher, H.S.; Kao, C.Y.; Fuhrman, F.A. Identity of tarichatoxin and tetrodotoxin. Science 1964, 143, 474-475.

26. Mosher, H.S.; Fuhrman, F.A.; Buchwald, H.D.; Fischer, H.G. Tarichatoxin-tetrodotoxin: A potent neurotoxin. Science 1964, 144, 1100-1110.

27. Narahashi, T. Tetrodotoxin: a brief history. Proc. Jpn. Acad., Ser. B Phys. Biol. Sci. 2008, 84 (5), 147-154. 
28. Hille, B. Ionic Channels of Excitable Membranes; Sinauer Associates; Macmillan: Sunderland, MA, USA, 2001.

29. Geffeney, S.; Ruben, C. The Structural Basis and Functional Consequences of Interactions Between Tetrodotoxin and Voltage-Gated Sodium Channels. Mar. Drugs 2006, 4 (3), 143-156.

30. Lipkind, G.M.; Fozzard, H.A. A structural model of the tetrodotoxin and saxitoxin binding site of the $\mathrm{Na}^{+}$channel. Biophys. J. 1994, 66 (1), 1-13.

31. Penzotti, J.L.; Fozzard, H.A.; Lipkind, G.M.; Dudley, S.C., Jr. Differences in saxitoxin and tetrodotoxin binding revealed by mutagenesis of the $\mathrm{Na}^{+}$channel outer vestibule. Biophys. $J$. 1998, 75 (6), 2647-2657.

32. Ishihara, F. 'Uber die physiologischen Wirkungen des Fugutoxins'. Mitteilungen aus der Medizinischen Fakultat der Kaiserlichen Universitat zu Tokyo = Tokyo Teikoku Daigaku Igakubu kiyo 1918, 20, 375-426.

33. Twitty, V.C. Experiments on the phenomenon of paralysis produced by a toxin occurring in Triturus embryos. J. Exp. Zool. A Comp. Exp. Biol. 1937, 76 (1), 67-104.

34. Twitty, V.C.; Elliot, A.E. The relative growth of the amphibian eye, studied by means of transplantation. J. Exp. Zool. A Comp. Exp. Biol. 1934, 68 (2), 247-291.

35. Twitty, V.C.; Johnson, H.H. Motor inhibition in Amblystoma produced by Triturus transplants. Science 1934, 80 (2064), 78-79.

36. Moore, J.W.; Narahashi, T. Tetrodotoxin's highly selective blockage of an ionic channel. Fed. Proc. 1967, 26 (6), 1655-1663.

37. Narahashi, T.; Deguchi, T.; Urakawa, M.; Ohkubo, Y. Stabilization and rectification of muscle fiber membrane by tetrodotoxin. Am. J. Physiol. Endocrinol. Metabol. 1960, 198, 934-938.

38. Narahashi, T.; Moore, J.W.; Scott, W.R. Tetrodotoxin blockage of sodium conductance increase in lobster giant axons. J. Gen. Physiol. 1964, 47, 965-974.

39. Narahashi, T. Mechanism of action of tetrodotoxin and saxitoxin on excitable membranes. Fed. Proc. 1972, 31 (3), 1124-1132.

40. Kao, C.Y. Structure-activity relations of tetrodotoxin, saxitoxin, and analogues. Ann. N.Y. Acad. Sci. 1986, 479, 52-67.

41. Kao, C.Y. Pharmacology of tetrodotoxin and saxitoxin. Fed. Proc. 1972, 31 (3), 1117-1123.

42. Lipkind, G.M.; Fozzard, H.A. KcsA crystal structure as framework for a molecular model of the $\mathrm{Na}(+)$ channel pore. Biochemistry 2000, 39 (28), 8161-8170.

43. Hinman, A.; Du Bois, J. A stereoselective synthesis of (-)-tetrodotoxin. J. Am. Chem. Soc. 2003, 125 (38), 11510-11511.

44. Yasumoto, T.; Yotsu-Yamashita, M. Chemical and etiological studies on tetrodotoxin and its analogs. J. Toxicol.: Toxin Rev. 1996, 15 (2), 81-90.

45. Kotaki, Y.; Shimizu, Y. 1-Hydroxy-5,11-dideoxytetrodotoxin, the first N-hydroxy and ringdeoxy derivative of tetrodotoxin found in the newt Taricha granulosa. J. Am. Chem. Soc. 1993, 115 (3), 827-830.

46. Kim, Y.H.; Brown, G.B.; Mosher, H.S.; Fuhrman, F.A. Tetrodotoxin: Occurrence in atelopid frogs of Costa Rica. Science 1975, 189, 151-152. 
47. Fuhrman, F.A.; Fuhrman, G.J.; Kim, Y.H.; Mosher, H.S. Pharmacology and chemistry of chiriquitoxin a new tetrodotoxin-like substance from the Costa Rican frog Atelopus chiriquiensis. Proc. West. Pharmacol. Soc. 1976, 19, 381-384.

48. Yotsu-Yamashita, M.; Mebs, D.; Yasumoto, T. Tetrodotoxin and its analogues in extracts from the toad Atelopus oxyrhynchus (family: Bufonidae). Toxicon 1992, 30 (11), 1489-1492.

49. Kao, C.Y.; Yeoh, P.N.; Goldfinger, M.D.; Fuhrman, F.A.; Mosher, H.S. Chiriquitoxin, a new tool for mapping ionic channels. J. Pharmacol. Exp. Ther. 1981, 217 (2), 416-429.

50. Daly, J.W.; Kaneko, T.; Wilham, J.; Garraffo, H.M.; Spande, T.F.; Espinosa, A.; Donnelly, M.A. Bioactive alkaloids of frog skin: combinatorial bioprospecting reveals that pumiliotoxins have an arthropod source. Proc. Natl. Acad. Sci. USA 2002, 99 (22), 13996-14001.

51. Yotsu-Yamashita, M.; Mebs, D. Occurrence of 11-oxotetrodotoxin in the red-spotted newt, Notophthalmus viridescens, and further studies on the levels of tetrodotoxin and its analogues in the newt's efts. Toxicon 2003, 41 (7), 893-897.

52. Pires, O.R.; Sebben, A.; Schwartz, E.F.; Bloch, C.; Morales, R.A.; Schwartz, C.A. The occurrence of 11-oxotetrodotoxin, a rare tetrodotoxin analogue, in the Brachycephalidae frog Brachycephalus ephippium. Toxicon 2003, 42 (5), 563-566.

53. Pires, O.R., Jr.; Sebben, A.; Schwartz, E.F.; Morales, R.A.; Bloch, C., Jr.; Schwartz, C.A. Further report of the occurrence of tetrodotoxin and new analogues in the Anuran family Brachycephalidae. Toxicon 2005, 45 (1), 73-79.

54. Hanifin, C.T.; Yotsu-Yamashita, M.; Yasumoto, T.; Brodie, E.D., III; Brodie, E.D., Jr. Toxicity of dangerous prey: variation of tetrodotoxin levels within and among populations of the newt Taricha granulosa. J. Chem. Ecol. 1999, 25 (9), 2161-2175.

55. Tsuruda, K.; Arakawa, O.; Noguchi, T. Toxicity and toxin profiles of the newt, Cynops pyrrhogaster from western Japan. J. Nat. Toxins 2001, 10 (2), 79-89.

56. Myers, G.S. Notes on Pacific Coast Triturus. Copeia 1942, 1942 (2), 77-82.

57. Twitty, V.C. Of Scientists and Salamanders. W.H. Freeman \& Co.: San Francisco, CA, USA, 1966.

58. Shindelman, J.; Mosher, H.S.; Fuhrman, F.A. Atelopidtoxin from the Panamanian frog, Atelopus zeteki. Toxicon 1969, 7, 315-319.

59. Wakely, J.F.; Fuhrman, G.J.; Fuhrman, F.A.; Fischer, H.G.; Mosher, H.S. The occurrence of tetrodotoxin (tarichatoxin) in amphibia and the distribution of the toxin in the organs of newts (Taricha). Toxicon 1966, 3 (3), 195-203.

60. Brodie, E.D., Jr.; Hensel, J.L.; Johnson, J.A. Toxicity of the Urodele amphibians Taricha, Notophthalmus, Cynops, and Paramesotriton (Salamandridae). Copeia 1974, 1974 (2), 506-511.

61. Tsuruda, K.; Arakawa, O.; Kawatsu, K.; Hamano, Y.; Takatani, T.; Noguchi, T. Secretory glands of tetrodotoxin in the skin of the Japanese newt Cynops pyrrhogaster. Toxicon 2002, 40 (2), $131-136$.

62. Levenson, C.H.; Woodhull, A.M. The occurrence of a tetrodotoxin-like substance in the redspotted newt, Notophthalmus viridescens. Toxicon 1979, 17, 184-187.

63. Brodie, E.D., Jr. Investigations on the skin toxin of the adult rough-skinned newt, Taricha granulosa. Copeia 1968, 1968 (2), 307-313. 
64. Hanifin, C.T.; Brodie, E.D., III; Brodie, E.D., Jr. A predictive model to estimate total skin tetrodotoxin in the newt Taricha granulosa. Toxicon 2004, 43 (3), 243-249.

65. Hanifin, C.T.; Brodie, E.D., III; Brodie, E.D., Jr. Tetrodotoxin levels in eggs of the rough-skin newt, Taricha granulosa, are correlated with female toxicity. J. Chem. Ecol. 2003, 29 (8), 1729-1739.

66. Shimizu, Y.; Kobayashi, M. Apparent lack of tetrodotoxin biosynthesis in captured Taricha torosa and Taricha granulosa. Chem. Pharm. Bull. (Tokyo) 1983, 31, 3625-3631.

67. Hanifin, C.T.; Brodie, E.D., Jr.; Brodie, E.D., III. Phenotypic mismatches reveal escape from arms-race coevolution. PLoS Biol. 2008, 6 (3), e60.

68. Twitty, V.C. Taricha rivularis (Twitty) red-bellied newt. In Catalogue of American Amphibians and Reptiles; Riemer, W.J., Ed.; American Society of Ichthyologists and Herpetologists: Kensington, MD, USA, 1964; pp. 9.1-9.2.

69. Sebben, A.; Schwartz, C.A.; Valente, D.; Mendes, E.G. A tetrodotoxin-like substance found in the Brazilian frog Brachycephalus ephippium. Toxicon 1986, 24 (6), 799-806.

70. Daly, J.W.; Gusovsky, F.; Myers, C.W.; Yotsu-Yamashita, M.; Yasumoto, T. First occurrence of tetrodotoxin in a dendrobatid frog (Colostethus inguinalis), with further reports for the bufonid genus Atelopus. Toxicon 1994, 32 (3), 279-285.

71. Pavelka, L.A.; Kim, Y.H.; Mosher, H.S. Tetrodotoxin and tetrodotoxin-like compounds from the eggs of the Costa Rican frog, Atelopus chiriquiensis. Toxicon 1977, 15, 135-139.

72. Mebs, D.; Schmidt, K. Occurrence of tetrodotoxin in the frog Atelopus oxyrhynchus. Toxicon 1989, 27 (7), 819-822.

73. Mebs, D.; Yotsu-Yamashita, M.; Yasumoto, T.; Lotters, S.; Schluter, A. Further report of the occurrence of tetrodotoxin in Atelopus species (family: Bufonidae). Toxicon 1995, 33 (2), 246-249.

74. Daly, J.W.; Padgett, W.L.; Saunders, R.L.; Cover, J.F., Jr. Absence of tetrodotoxins in a captiveraised riparian frog, Atelopus varius. Toxicon 1997, 35 (5), 705-709.

75. Brown, G.B.; Kim, Y.H.; Kuntzel, H.; Mosher, H.S. Chemistry and pharmacology of skin toxins from the frog Atelopus zeteki (atelopidtoxin: zetekitoxin). Toxicon 1977, 15 (2), 115-128.

76. Tanu, M. B.; Mahmud, Y.; Tsuruda, K.; Arakawa, O.; Noguchi, T. Occurrence of tetrodotoxin in the skin of a rhacophoridid frog Polypedates sp from Bangladesh. Toxicon 2001, 39 (7), 937-941.

77. Hirota, K.; Kaneko, Y. Cloning and distribution of a putative tetrodotoxin-resistant $\mathrm{Na}+$ channel in newt retina. Zool. Sci. 1999, 16, 587-594.

78. Kaneko, Y.; Matsumoto, G.; Hanyu, Y. TTX resistivity of $\mathrm{Na}+$ channel in newt retinal neuron. Biochem. Biophys. Res. Commun. 1997, 240, 651-656.

79. Williams, B.L. Behavioral and chemical ecology of marine organisms with respect to tetrodotoxin. Mar. Drugs 2010, 8, 381-398.

80. Brodie, E.D., III; Brodie, E.D., Jr. Costs of exploiting poisonous prey: evolutionary trade-offs in a predator-prey arms race. Evolution 1999, 53 (2), 626-631.

81. Lee, P.; Ruben, P.C. The Biophysical Costs Associated with Tetrodotoxin Resistance in the Garter Snake, Thamnophis sirtalis. Mar. Drugs 2010, 8, submitted. 
82. Duellman, W.E.; Trueb, L. Biology of Amphibians, 1st ed.; McGraw-Hill: New York, NY, USA, 1986.

83. Daly, J.W. The chemistry of poisons in amphibian skin. Proc. Natl. Acad. Sci. USA 1995, 92 (1), 9-13.

84. Brodie, E.D., Jr. Antipredator adaptations of salamanders: evolution and convergence among terrestrial species. In Plant, animal, and microbial adaptations to terrestrial environment; Margaris, N.S., Arianoutsu-Faraggitaki, M., Reiter, R.J., Eds.; Plenum: New York, NY, USA, 1983.

85. Brodie, E.D., Jr.; Ducey, P.K.; Baness, E.A. Antipredator Skin Secretions of Some Tropical Salamanders (Bolitoglossa) are Toxic to Snake Predators. Biotropica 1991, 23 (1), 58-62.

86. Tyler, M.J. Frog and cane toad secretions. In Toxic Plants and Animals: A Guide for Australia; Covacevich, J., Davies, P.; Pearn, J., Eds.; Qld. Museum: Brisbane, Australia, 1987.

87. Erspammer, V. Bioactive secretions of amphibian integument. In Amphibian Biology; Heatwole, H., Barthalmus, G.T., Eds.; Surrey Beatty \& Sons Pty., Ltd.: Chipping Norton, UK, 1994.

88. Duda, T.F., Jr.; Vanhoye, D.; Nicolas, P. Roles of diversifying selection and coordinated evolution in the evolution of amphibian antimicrobial peptides. Mol. Biol. Evol. 2002, 19 (6), $858-864$.

89. Erspamer, V.; Erspamer, G.F.; Mazzanti, G.; Endean, R. Active peptides in the skins of one hundred amphibian species from Australia and Papua New Guinea. Comp. Biochem. Physiol. 1984, 77C (1), 99-108.

90. Mangoni, M.L.; Maisetta, G.; Di Luca, M.; Gaddi, L.M.; Esin, S.; Florio, W.; Brancatisano, F.L.; Barra, D.; Campa, M.; Batoni, G. Comparative analysis of the bactericidal activities of amphibian peptide analogues against multidrug-resistant nosocomial bacterial strains. Antimicrob. Agents Chemother. 2008, 52 (1), 85-91.

91. Brodie, E.D., Jr.; Nussbaum, R.A.; DiGiovanni, M. Antipredator adaptations of Asian salamanders (Salamandridae). Herpetologica 1984, 40 (1), 56-68.

92. Johnson, J.A.; Brodie, E.D., Jr. The selective advantage of the defensive posture of the newt, Taricha granulosa. Am. Midl. Nat. 1975, 93 (1), 139-148.

93. Neuwirth, M.; Daly, J.W.; Myers, C.W.; Tice, L.W. Morphology of the granular secretory glands in skin of poison-dart frogs (Dendrobatidae). Tissue Cell 1979, 11 (4), 755-771.

94. Chen, T.; Farragher, S.; Bjourson, A.J.; Orr, D.F.; Rao, P.; Shaw, C. Granular gland transcriptomes in stimulated amphibian skin secretions. Biochem. J. 2003, 371 (Pt 1), 125-130.

95. Kim, H.-H.; Noh, Y.-T.; Chung, Y.-W.; Chi, Y.-D. The ultrastructure of the mucous secreting cells in the amphibians skin. Korean J. Zool. 1978, 21 (1), 29-39.

96. Elkan, E.; Cooper, J.E. Skin Biology of Reptiles and Amphibians. Proc. R. Soc. Edinburgh 1980, $79 b, 115-125$.

97. Hoffman, C.W.; Dent, J.N. Effects of neurotransmitters upon the discharge of secretory product from the cutaneous glands of the red-spotted newt. J. Exper. Zool. 1977, 202, 155-162.

98. Toledo, R.C.; Jared, C. Cutaneous granular glands and amphibian venoms. Comp. Biochem. Physiol. A: Physiol. 1995, 111A (1), 1-29. 
99. Williams, B.L.; Brodie, E.D., III; Brodie, E.D., Jr. A resistant predator and its toxic prey: persistence of newt toxin leads to poisonous (not venomous) snakes. J. Chem. Ecol. 2004, 30 (10), 1901-1919.

100. Fuhrman, F.A.; Fuhrman, G.J.; Dull, D.L.; Mosher, H.S. Toxins from eggs of fishes and amphibia. J. Agric. Food Chem. 1969, 17, 417-424.

101. Gregory, P.T.; Nelson, K.J. Predation on fish and intersite variation in the diet of common garter snakes, Thamnophis sirtalis, on Vancouver Island. Can. J. Zool./Rev. Can. Zool. 1991, 69, 988-994.

102. Macartney, J.M.; Gregory, P.T. Differential susceptibility of sympatric garter snake species to amphibian skin secretions. Am. Midl. Nat. 1981, 106 (2), 271-281.

103. Brandon, R.A.; Labanick, G.M.; Huheey, J.E. Learned avoidence of brown efts, Notophthalmus viridescen louisianensis (Amphibia, Urodela, Salamandridae), by chickens. J. Herpetol. 1979, 13 (2), 171-176.

104. Brodie, E.D., Jr. Investigations on the Skin Toxin of the Red-Spotted Newt, Notophthalmus viridescens viridescens. Am. Midl. Nat. 1968, 80 (1), 276-280.

105. Brodie, E.D., Jr.; Formanowicz, D.R., Jr. Larvae of the predaceous diving beetle Dytiscus verticalis acquire an avoidance response to skin secretions of the newt Notophthalmus viridescens. Herpetologica 1981, 37 (3), 172-176.

106. Hurlbert, S.H. Predator Responses to the Vermilion-Spotted Newt (Notophthalmus viridescens). J. Herpetol. 1970, 4 (1/2), 47-55.

107. Pough, F.H. Leech-repellent property of eastern red-spotted newts, Notophthalmus viridescens. Science 1971, 174, 1144-1146.

108. Shure, D.J.; Wilson, L.A.; Hochwender, C. Predation on aposematic efts of Notophthalmus viridescens. J. Herpetol. 1989, 23 (6), 437-439.

109. Webster, D.A. Toxicity of the spotted newt, Notophthalmus viridescens, to trout. Copeia 1960, 1960 (1), 2.

110. Brodie, E.D., III; Brodie, E.D., Jr. Tetrodotoxin resistance in garter snakes - an evolutionary response of predators to dangerous prey. Evolution 1990, 44 (3), 651-659.

111. Brodie, E.D., Jr.; Ridenhour, B.J.; Brodie, E.D., III. The evolutionary response of predators to dangerous prey: hotspots and coldspots in the geographic mosaic of coevolution between garter snakes and newts. Evolution 2002, 56 (10), 2067-2082.

112. Feldman, C.R.; Brodie, E.D., Jr.; Brodie, E.D., 3rd; Pfrender, M.E. The evolutionary origins of beneficial alleles during the repeated adaptation of garter snakes to deadly prey. Proc. Natl. Acad. Sci. USA 2009, 106 (32), 13415-13420.

113. Geffeney, S.L.; Fujimoto, E.; Brodie, E.D., III; Brodie, E.D., Jr.; Ruben, P.C. Evolutionary diversification of TTX-resistant sodium channels in a predator-prey interaction. Nature 2005, 434 (7034), 759-763.

114. Brodie, E.D., III; Brodie, E.D., Jr. Evolutionary response of predators to dangerous prey reduction of toxicity of newts and resistance of garter snakes in island populations. Evolution 1991, 45 (1), 221-224. 
115. Brodie, E.D., III; Feldman, C.R.; Hanifin, C.T.; Motychak, J.E.; Mulcahy, D.G.; Williams, B.L.; Brodie, E.D., Jr. Parallel arms races between garter snakes and newts involving tetrodotoxin as the phenotypic interface of coevolution. J. Chem. Ecol. 2005, 31 (2), 343-356.

116. Geffeney, S.L.; Brodie, E.D., Jr.; Ruben, P.C.; Brodie, E.D., III. Mechanisms of adaptation in a predator-prey arms race: TTX-resistant sodium channels. Science 2002, 297 (5585), 1336-1339.

117. Gall, B.G.; Brodie, E.D., III; Brodie, E.D., Jr. Predator avoidance during oviposition: female newts avoid depositing eggs near invertebrate predators. Copeia 2010, submitted.

118. Zimmer, R.K.; Ferrer, R.P. Neuroecology, chemical defense, and the keystone species concept. Biol. Bull. Mar. Biol. Lab. Woods Hole 2007, 213 (3), 208-225.

119. Kuchta, S.R. Experimental support for aposematic coloration in the salamander Ensatina eschscholtzii xanthoptica: Implications for mimicry of Pacific Newts. Copeia 2005 (2), $265-271$.

120. Kuchta, S.R.; Krakauer, A.H.; Sinervo, B. Why does the yellow-eyed Ensatina have yellow eyes? Batesian mimicry of Pacific newts (genus Taricha) by the salamander Ensatina eschscholtzii xanthoptica. Evolution 2008, 62 (4), 984-990.

121. Howard, R.R.; Brodie, E.D. Experimental study of mimicry in salamanders involving Notophthalmus viridescens viridescens and Pseudotriton ruber schencki. Nature 1971, 233 (5317), 277.

122. Huheey, J.E.; Brandon, R.A. Studies in warning coloration and mimicry. VI. Comments on the warning coloration of red efts and their presumed mimicry by red salamanders. Herpetologica 1974, 30 (2), 149-155.

123. Ferrer, R.P.; Zimmer, R.K. Chemical neuroecology and community dynamics. Ann. N.Y. Acad. Sci. 2009, 1170, 450-455.

124. Zimmer, R.K.; Schar, D.W.; Ferrer, R.P.; Krug, P.J.; Kats, L.B.; Michel, W.C. The scent of danger: Tetrodotoxin (TTX) as an olfactory cue of predation risk. Ecol. Monogr. 2006, 76 (4), 585-600.

125. Chau, R.; Kalaitzis, J.A.; Neilan, B.A. Biosynthesis of tetrodotoxin and structurally related molecules. Mar. Drugs 2010, 8, submitted.

126. Matsumura, K. Reexamination of tetrodotoxin production by bacteria. Appl. Environ. Microbiol. 1995, 61, 3468-3470.

127. Janzen, F.J.; Krenz, J.G.; Haselkorn, T.S.; Brodie, E.D., Jr.; Brodie, E.D., III. Molecular phylogeography of common garter snakes (Thamnophis sirtalis) in western North America: implications for regional historical forces. Mol. Ecol. 2002, 11 (9), 1739-1751.

Samples Availability: Available from the authors.

(C) 2010 by the authors; licensee Molecular Diversity Preservation International, Basel, Switzerland. This article is an open-access article distributed under the terms and conditions of the Creative Commons Attribution license (http://creativecommons.org/licenses/by/3.0/). 